\title{
Development of Inquiry-Based Multimedia Learning Module with PhET Simulation in Newton's Law of Motion
}

\author{
Dian Sukma Luliyarti ${ }^{1, *}$ Zuhdan Kun Prasetyo ${ }^{2}$ \\ ${ }^{1}$ Physics Education, Graduate School, Universitas Negeri Yogyakarta \\ ${ }^{2}$ Science Education, Universitas Negeri Yogyakarta \\ *Corresponding author.Email: diansukma.2018@student.uny.ac.id
}

\begin{abstract}
This research is development research with a 4-D model (define, design, develop, and spread) about Newton's laws of motion. The purpose of this research is to determine the feasibility of Multimedia Learning Module (MLM) products developed in physics learning. The MLM product that is designed is then tested for its feasibility by the validator. Product validation was carried out using descriptive analysis and the average value was obtained on the material aspects of 96.15 and the media aspects of 96.43 so that they were included in the very feasible category. MLM was then tried out with a cluster random sampling technique on 26 students of SMA Negeri 1 Sleman to get student responses to the product. The trial was carried out by providing questionnaire responses to students and analyzed using descriptive analysis. The trial results in the form of student responses to MLM products obtained a value of 79.87 so that it is included in the feasible category. Therefore, the MLM developed is feasible and can be used in physics learning in school.
\end{abstract}

Keywords: Multimedia Learning Module, Inquiry, PhET Simulation, Newton's Law Material.

\section{INTRODUCTION}

The development of the world has now been influenced by science and technology. One example is educational technology. Educational technology is a science that is supported by the domain of utilization [1]. This technology has made learning machines the main element and data acquisition has become more abundant. This is due to the growing digitalization and computational capabilities [2] and changes in the types of technology and information [3]. Learning in this technology is designed so that it can provide better images, diagrams, and screen displays in the learning environment [3].

Learning with visual media has developed so that additional sound is needed into the visual, then new concepts about learning using audiovisual are emerging. Learning is done with the main focus to develop students' knowledge through the senses of the eyes and ears [4]. One such technology mentioned is learning with multimedia. Multimedia learning uses communication that contains words and images to enhance learning. Communication can be conveyed through any media, including paper, which is book based communication or computer, that is computer-based communication. Words can include printed words used to read or spoken words such as in narration, images can include static images such as illustrations or photos or dynamic images such as animations or video clips. Besides, textbooks, online lessons that contain animation and narration, and interactive simulation games are included [5].

Students have now been facilitated with textbooks, but printed textbooks have limitations in the presentation of material. The limitations of print media open the opportunity for integrating a teaching material with the latest information technology [6]. One of them is like a multimedia learning module (MLM). MLM shows the concepts of physics through text, images, animations, and videos [7]. MLM is designed to foster student involvement based on their own learning experiences [8]. 
Sudent learning experiences are carried out through learning models such as inquiry. Inquiry guides students in the process of thinking, discussing ideas, developing explanations based on evidence, and communicating ideas [9]. Inquiry learning is aimed at directing students to develop the ability to reason and think in an inquiry process [10-15]. Inquiry-based learning requires a relatively long time in the process of preparation and implementation in the classroom [16-17]. Therefore, the investigation can be carried out by utilizing virtual technology such as PhET simulation.

PhET simulations are designed to allow the stage of inquiry to be carried out quickly, pleasantly, and interactively, allowing to connect to a more real-world and providing multiple representations [18]. Simulation can involve conceptual or abstract representations of objects that are conceptual and not visible in the real world, thus providing insight into the visible or invisible aspects of a phenomenon through the multirepresentation nature. Therefore, students can understand the phenomenon more deeply [19]. Besides, the PhET simulation provides a safe learning environment [20]. Simulation can be used to develop special skills, where the development of theories, concepts, and principles is done by providing material, textbooks, or others [21] such as MLM.

Learning physics in Newton's law material about motion is still difficult for students. Students are unable to determine the coordinate axis, draw force diagrams, represent forces, and are still lacking in determining the magnitude and direction of motion of objects [22]. This can be caused by students who tend to refer more to mathematical formulations in solving physical problems without a basic understanding of concepts about various phenomena in the material. Therefore, researchers developed an inquiry-based MLM with a PhET simulation on Newton's laws of motion.

\section{THE METHOD OF RESEARCH}

\subsection{The Development Style}

This type of research used in this research is research and development $(\mathrm{R} \& \mathrm{D})$ with a development model that refers to the four D model (4-D model). The 4-D model consists of define, design, develope, and dessiminate. The development procedure used in this study uses a 4-D model with four stages [23].

\subsubsection{Define Phase}

The development research model at this stage is defining needs in the learning process. Activities at this stage are needs analysis, student analysis, curriculum analysis, and material analysis. Needs analysis is carried out to determine the problems that underlie the development of inquiry-based MLM with PhET simulation in physics learning. Student analysis is carried out to determine the characteristics of students so that they can be following the design and development of MLM. Curriculum analysis is carried out to identify the curriculum to the competencies to be achieved. Material analysis is carried out to identify and elaborate on the concepts of physics in the material so that it can be arranged and described in a detailed and systematic manner.

\subsubsection{Design Phase}

The development research model at this stage is defining needs in the learning process. Activities at this stage are needs analysis, student analysis, curriculum analysis, and material analysis. Needs analysis is carried out to determine the problems that underlie the development of inquiry-based MLM with PhET simulation in physics learning. Student analysis is carried out to determine the characteristics of students so that they can be following the design and development of MLM. Curriculum analysis is carried out to identify the curriculum to the competencies to be achieved. Material analysis is carried out to identify and elaborate on the concepts of physics in the material so that it can be arranged and described in a detailed and systematic manner.

\subsubsection{Develope Phase}

The develope phase is carried out to modify the product in the form of results at the design stage, then the modification will be validated by the validator. The develope phase will produce a product that has been tested for eligibility by a validator and trial.

The product feasibility stage is carried out to assess the feasibility of a good product that can be used in trials. Product feasibility is carried out by experts consisting of lecturers, appointed teachers, and peers. The results, comments and suggestions are then made the basis for revision.

A trial is conducted to read limited to MLM that discusses the use of sentences about the rules of the Indonesian language, the use of features in MLM so that it cannot be used and can be used, the display with the appropriate color and layout features, and students' responses to MLM with the help of a student responses questionnaire. Limited trials were conducted on a limited number of students in SMA Negeri 1 Ngemplak, Sleman.

\subsubsection{Disseminate Phase}

The disseminate phase is carried out to develop products that are useful for others. This stage is the last stage of the 4-D model which is carried out with the distribution of the final product which has been assessed as feasible to students, dissemination will also be done 
through seminars or submit articles and submission of copyrights. The following is presented in Figure 1 which shows the stages in the research.

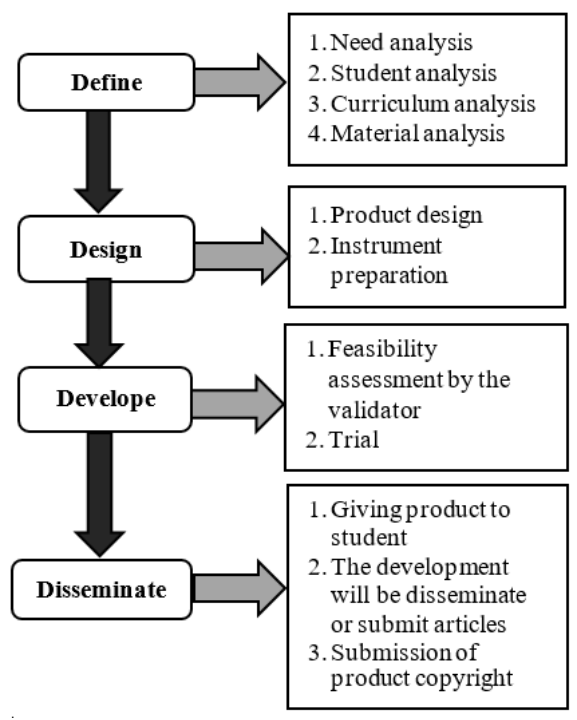

Figure 1 The phase of research.

\subsection{The Population and Sample of Research}

The population is all of classes XI students in SMA Negeri 1 Ngemplak, Sleman in the 2019/2020 academic year. Cluster random sampling techniques were used to taken the sample of this research and obtained class XI Mipa 2 with a total of 26 students as the trial class.

\subsection{The Data Collection and Instruments Techniques}

The data collection techniques carried out to collect the required data. The techniques used to collect data in this study are non-test techniques in the form of questionnaires, observation sheets, interviews and documentation. Data collection instruments used in the study are explained as follows.

\subsubsection{Product Feasibility Assessment Sheet.}

The product feasibility assessment sheet is used to find out whether the developed MLM is feasible for use in physics learning or not. This assessment sheet is made for the assessment of material aspects and media aspects.

\subsubsection{Student Response Questionnaire Assessment Sheet.}

This assessment sheet is used to validate each item of the student response questionnaire statement to measure students' responses to the product.

\subsubsection{Student Response Questionnaire Sheet.}

Student response sheets are used to view product readability by students. Respon questionnaire containing statements and comments and suggestions from students is then analyzed and used to obtain information in product improvement. Questionnaire responses of students to the product include aspects of learning, language, appearance, media operations, and media benefits.

\subsection{The Data Analysis Technique}

The data analysis technique consist of product feasibility analysis, content validation analysis of the student response questionnaire, and analysis of student response results.

\subsubsection{Product Feasibility Analysis}

This analysis is carried out on the results of the product feasibility assessment with stages are calculate the average size of scores on each aspect of the assessment and then change the score into a value. This stage uses the equation:

$\overline{\mathrm{x}}=\frac{\sum \mathrm{x}}{\mathrm{n}}$

Information:

$\overline{\mathrm{x}} \quad$ : Average of score

$\sum \mathrm{x}:$ Number of score

$\mathrm{n}$ : Number of validator

Convert the scores to a scale of five according to [24] with the first step is calculate the ideal average score with the equation:

$\mathrm{X}_{\mathrm{i}}=\frac{1}{2}$ (ideal maximum score +

ideal minimum score)

Ideal maximum score $=\sum$ item criterion $\times$ maximum score

Ideal minimum score $=\sum$ item criterion $\times$ minimum score

Second step is determine the ideal standard deviation with the equation:

$\mathrm{Sb}_{\mathrm{i}}=\frac{1}{6}$ (ideal maximum score +

ideal minimum score)

Finally is determine the assessment results criteria based on the criteria in Table 1.

\subsubsection{Content Validation Analysis of The Student Response Questionnaire.}

Validation analysis of the contents of the non-test instrument was conducted on the questionnaire of 
Table 1. Five scale of assessment criteria.

\begin{tabular}{|c|c|c|}
\hline Range of Score & Achievement Criteria & Category \\
\hline$X>\overline{X_{t}}+1.8 S B i$ & $X>85$ & Very feasible \\
\hline$\overline{X_{t}}+0.6 S B i<X \leq \overline{X_{t}}+1.8 S B i$ & $70<\mathrm{X} \leq 85$ & Feasible \\
\hline$\overline{X_{t}} s-0.6 S B i<X \leq \overline{X_{t}}+0.6 S B i$ & $55<\mathrm{X} \leq 70$ & Pretty feasible \\
\hline$\overline{X_{t}}-1.8 S B i<X \leq \overline{X_{t}}-0.6 S B i$ & $40<\mathrm{X} \leq 55$ & Not worth it \\
\hline$X \leq \overline{X_{t}}-1.8 S B i$ & $\mathrm{X} \leq 40$ & Very poor \\
\hline
\end{tabular}

students' responses using the Aiken's V equation which refers to the results of the assessment by the validator with the number of people. The experts write a value with a range 1-4 along with comments on each item, researchers make improvements based on comments from experts. Data analysis was performed using the following equation:

$\mathrm{V}=\frac{\sum \mathrm{s}}{\mathrm{n}(\mathrm{c}-1)}=\frac{\sum\left(\mathrm{r}-\mathrm{l}_{0}\right)}{\mathrm{n}(\mathrm{c}-1)}$

Information:

$\mathrm{V}$ : Aikens validity value

$r \quad$ : Number given by a validator

$\mathrm{I}_{0} \quad$ : The lowest validity number

$\mathrm{n} \quad$ : Number of validators

c : The lowest validity number

The item is said to be valid if the minimum Aiken coefficient value is the same as the minimum value in the Aiken table [25]. This validation was carried out by 7 validators with 3 assessment categories, so the minimum Aiken coefficient that must be obtained is 0.86 so that the statement is said to be valid.

\subsubsection{Analysis of Student Response.}

The average score on each aspect of the assessment is calculated and turns the score into a score. Then the score is categorized into a scale of five as in Table 1.

\section{THE RESULT AND DISCUSSION OF RESEARCH}

This section explains the results and discussion of the research.

\subsection{Material Feasibility Assessment}

Instrument produces qualitative data in the form of suggestions and comments for improvement of material and quantitative data in the form of a feasibility score with a range of 1-4 by established indicators. Aspects of the assessment of the feasibility of the material are divided into aspects of the introduction, aspects of the contents, and closing aspects as well as aspects of language. The results of the analysis activity obtained an average product evaluation from material experts of 3.85 with a value of 96.15 given in Table 2 .

Comments and suggestions obtained that are using effective language and concepts, then writing of physical quantities still need to be improved.

Table 2. Results of product evaluation from material aspects.

\begin{tabular}{|l|c|c|}
\hline \multicolumn{1}{|c|}{ Aspect } & Assessment & Category \\
\hline Introduction & 97.86 & Very feasible \\
\hline Contents & 97.62 & Very feasible \\
\hline Cover & 100 & Very feasible \\
\hline Language & 83.93 & Feasible \\
\hline
\end{tabular}

\subsection{Media Feasibility Assessment}

The media feasibility assessment instrument produces qualitative data in the form of suggestions and comments for material improvement and quantitative data in the form of a feasibility score with a range of 1-4 following established indicators. The aspects of media feasibility assessment are divided into aspects of software display and engineering. The results of the analysis activity obtained an average product evaluation from media experts of 3.86 with a value of 96.43 given in Table 3. The acquisition of these values is included in the very feasible category.

Table 3. Results of product evaluation from media aspects.

\begin{tabular}{|l|c|c|}
\hline \multicolumn{1}{|c|}{ Aspect } & Assessment & Category \\
\hline Display & 94.64 & Very feasible \\
\hline Software engineering & 100 & Very feasible \\
\hline
\end{tabular}

Comments and suggestions obtained are still needed consistency in the navigation buttons on the media.

\subsection{Validation of Student Response Questionnaire}

Questionnaire responses of students first conducted content validation. This is done with the aim that the instruments used can measure what should be measured. Assessments are carried out by experts, teachers, and peers. The questionnaire responses of students consist of 29 statements. The results of the analysis using Aiken's $\mathrm{V}$ are in the range of scores of $0.86-1.00$, so it can be said 
that 29 items are valid statements and can be used to the limited trial phase.

\subsection{Trial}

The product trial was conducted on 26 students of class XI Mipa at SMA Negeri 1 Ngemplak because at SMA 1 Ngemplak there had never been a trial on MLM development. The trial was carried out after the inquirybased MLM product with a revised PhET simulation based on expert comments and suggestions. Trials are conducted by giving questionnaires to students' responses to the product. The trial aims to find out the readability of the product. The following is shown in Table 4 for the results of a trial analysis.

Table 4. Trial results.

\begin{tabular}{|l|c|l|}
\hline \multicolumn{1}{|c|}{ Aspect } & Assessment & Category \\
\hline Learning & 82.34 & Feasible \\
\hline Language & 75.64 & Feasible \\
\hline Display & 81.73 & Feasible \\
\hline Media operations & 82.37 & Feasible \\
\hline Benefit of media & 77.24 & Feasible \\
\hline \multicolumn{2}{|r}{} \\
\hline
\end{tabular}

Based on Table 3 it can be said that the results of trial to knowing the product readability is included in the category feasible for use with an average value of 79.87. The students' comments and suggestions are 1) the investigation activity sheet is further shortened, 2) the media is good because it is different froms the others, 3) MLM makes learning easier because the delivery of the material is not monotonous and not boring and 4) it looks good, there are pictures so it's quite easy to understand, the buttons on the media are not confusing and interesting because there is audio.

\subsection{Product}

Inquiry-based MLM with PhET simulation is developed through the 4-D development stage. MLM is feasible to use in learning physics based on the results of the analysis of the feasibility assessment, validation, and trial. This MLM contains all learning activities that contain an inquiry activity sheet, materials, sample questions, practice questions, and quizzes. The following is the product display image.

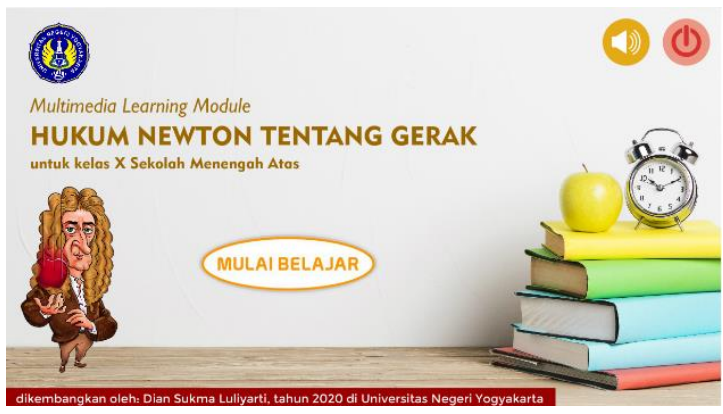

Figure 2 MLM initial display.

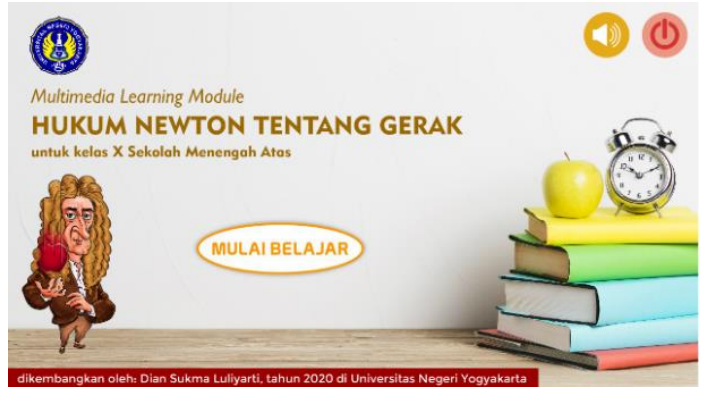

Figure 3 The initial stage of inquiry.

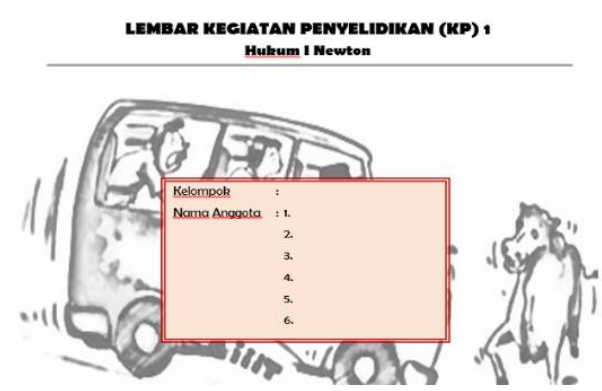

Figure 4 Inquiry activity sheet.

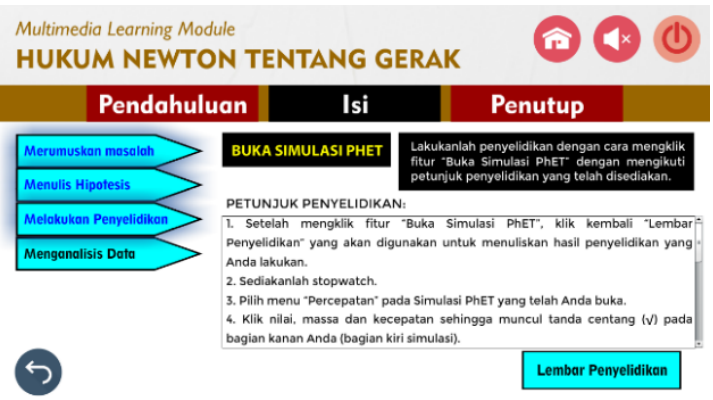

Figure 5 PhET simulation at MLM.

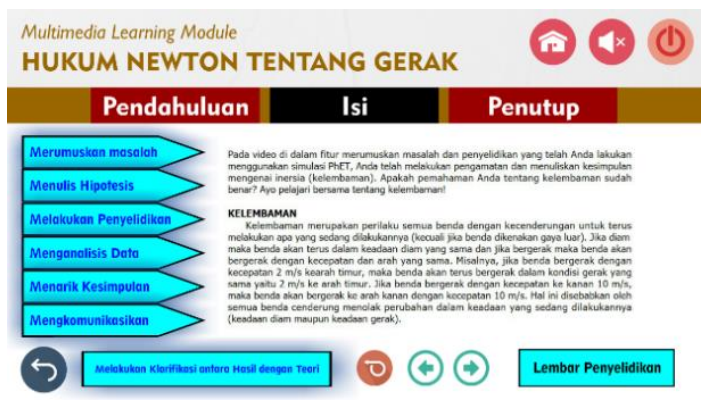

Figure 6 Newton's law material of motion.

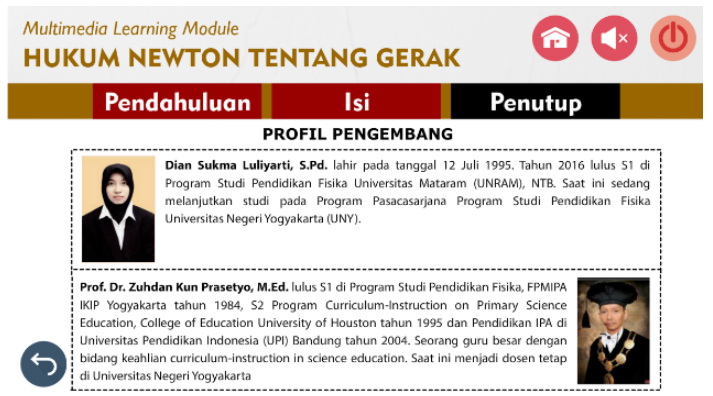

Figure 7 The developer profile. 


\section{CONCLUSION}

The MLM is assessed by expert lecturers, teachers, and peers to determine the feasibility of the MLM that has been designed. This assessment shows that MLM is feasibly using and trying out. Furthermore, a trial is conducted to determine students' responses to MLM products. Trials show that MLM is in the feasible category. Based on the assessment by experts, teachers, peers, and students, the inquiry-based MLM with PhET simulations can be used as a medium in the physics learning process because the assessment includes in the feasible category. This is supported by research [26] which states that MLM is very feasible for use in learning.

\section{REFERENCES}

[1] B. Barokah, D.D. Kaligis, P.T.D. Rompas, Y. Wibisono, W. Wiratno, R.W. Batubara, The effect of computer-based learning on learning outcome of diesel engine learning, in: IOP Conf. Ser.: Mater. Sci. Eng, 830 032023, 2020.

[2] O.A. Von Lilienfeld, Introducing machine learning: science and technology, in: Machine Learning: Science and Technology, 1 010201, 2020.

[3] D. Mutlu-Bayraktar, V. Cosgun, T. Altan, Cognitive load in multimedia learning environments: a systematic review, in: Computers \& Education, 141, 2019.

[4] M. Yaumi, Media dan teknologi pembelajaran, Jakarta, Prenada Media, 2018.

[5] R. Mayer, R.E. Mayer, The cambridge handbook of multimedia learning, Cambridge, Cambridge University Press, 2005.

[6] F. Kimianti, Z.K. Prasetyo, Pengembangan e-modul IPA berbasis problem based learning untuk meningkatkan literasi sains siswa, in: Kwangsan, 7 295728, 2019.

[7] A. Setiyadi, R.S. Darma, I. Wilujeng, H. Kuswanto, Mathematical representations mapping of high school students after using multimedia learning modules assisted by an android smartphone, in: $\mathrm{J}$. Phys.: Conf. Ser, 1233 012049, 2019.

[8] H.R. Sadaghiani, Controlled study on the effectiveness of multimedia learning modules for teaching mechanics, in: Physical Review Special Topics-Physics Education Research, 8 010103, 2012.

[9] E.B. Moore, T.A. Herzog, K.K. Perkins, Interactive simulations as implicit support for guided-inquiry in: Chemistry Education Research and Practice, 14 257-68, 2013.
[10] D.A. Uswatun, E. Rohaeti, Perangkat pembelajaran IPA berbasis inkuiri untuk meningkatkan critical thinking skills dan scientific attitude siswa, in: Jurnal Inovasi Pendidikan IPA, vol. 1, 2015, pp. 138-52.

[11] N.A.C. Darnawati, E.A. Juanda, The effect of inquiry based learning on the reasoning ability of grade VII students about heat concept, in: Jurnal Pendidikan Fisika Indonesia, vol. 12, 2016, pp. 1925.

[12] M. Duram, I. Dokme, The effect of the inquirybased learning approach on student's criticalthinking skills, in: Eurasia Journal Of Mathematics, Science \& Technology Education, 12 2887-908, 2016.

[13] S. Zubaidah, N.M. Fuad, Mahanal, E. Suarsini, Improving creative thinking skills of students through differentiated science inquiry integrated with mind map, in: Journal Of Turkish Science Education, vol. 14, 2017, pp. 77-91.

[14] M. Firdaus, I. Wilujeng, Pengembangan LKPD inkuiri terbimbing untuk meningkatkan keterampilan berpikir kritis dan hasil belajar peserta didik, in: Jurnal Inovasi Pendidikan IPA, vol. 4, 2018, pp. 26-40.

[15] E.K. Nisa, T. Koestiari, M. Habibulloh, B. Jatmiko, Effectiveness of guided inquiry learning model to improve students' critical thinking skills at senior high school, in: Journal Of Physics: Conf. Series, 997, 2018.

[16] R.I.P. Hartini, Penggunaan levels of inquiry dalam meningkatkan keterampilan proses sains siswa, in: Jurnal Ilmu Pendidikan Fisika, vol. 2, 2017, pp. 1924.

[17] U. Ramnarain, M. Hlatswayo, Teacher beliefs and attitudes about inquiry-based learning in a rural school district in south africa, in: South African Journal Of Education, 38 1431-41, 2018.

[18] J.P. Suits, M.J. Sanger, Pedagogic roles of animations and simulations, in: Chemistry Sourses, American Chemical Society, 2013.

[19] G. Olympiou, Z. Zacharias, T. deJong, Making the invisible visible: enhancing students' conceptual understanding by introducing representations of abstract objects in a simulation, in: Instructional Science, 41 575-96, 2012.

[20] J.M. Chamberlain, K. Lancaster, R. Parson, K.K. Perkins, How guidance affects student engagement with an interactive simulation, in: Chemistry Education Research and Practice, 15 628-38, 2014. 
[21] C. Wankel, P. Blessinger, Increasing student engagement and retention using immersive interfaces: virtual worlds, gaming, and simulation, UK, Emerald Group Publishing, 2012.

[22] S. Zhou, C. Zhang, H. Xiao, Students' understanding on newton's third law in identifying the reaction force in gravity interactions, in: Eurasia Journal of Mathematics, Science \& Technology Education, 11 589-99, 2015.

[23] S. Triagarajan, D.S. Semmel, M.I. Semmel, Instructional development for training teachers of exceptional children, in: A Sourcebook, Indiana, Indiana University Bloomington, 1974.

[24] Sukardjo, Buku pegangan kuliah evaluasi pembelajaran IPA, Yogyakarta, Program Studi Pendidikan Sains Program Pascasarjana UNY, 2012.

[25] L.R. Aiken, Three coefficients for analysing the reliability and validity of ratings, in: Educational and Psychological Measurement, 45 131-42, 1985.

[26] R.S. Darma, Nursuhud, D.A. Oktavia, A. Setiyadi, The development of physics learning media based on local wisdom belogo and traditional rowing contest to improve the physics representative ability of high school students in realizing learning outcomes, in: International Conference on Educational Research and Innovation (ICERI 2019, 2020, pp. 79-84. 